\title{
Entrepreneurial orientation and venture performance in Ethiopia: the moderating role of business sector and enterprise location
}

\author{
Abdella Kosa ${ }^{1 *}$, Idris Mohammad ${ }^{2}$ and Dereje Ajibie ${ }^{3}$
}

\footnotetext{
*Correspondence: abdikosa@gmail. com

${ }^{1}$ Department of Entrepreneurship and Business Management, Kotebe Metropolitan University, Addis Ababa, Ethiopia

Full list of author information is available at the end of the article
}

\begin{abstract}
Entrepreneurial orientation in different perspective contributes to the success of ventures differently. Therefore, this study aimed to investigate the contribution of entrepreneurial orientation towards the performance of small ventures in the context of different business sectors and the location of the businesses. To achieve this objective, the primary data was obtained from a sample of 210 small firms which were selected from the central part of Ethiopia using two level multi-stage sampling. The finding of the study indicates that entrepreneurial orientation positively influences ventures performance, but it will determine more when enterprises are established in city areas and involved in the industry sector. Therefore, the owner/ managers of enterprises should improve their practices of entrepreneurial orientation by introducing new lines, technologies, and market; improve workers' participation in developing new ideas and design; and compete aggressively by taking a calculated risk. Finally, our implication for further study is that future research has to compare the transited and failed enterprises in longitudinal studies to capture the progress of entrepreneurial orientation among transited and failed firms.
\end{abstract}

Keywords: Entrepreneurial orientation, Strategy, Performance, Small firms

\section{Background}

Given the current economic challenges facing many countries across the globe, the notion of engendering greater entrepreneurial activity has become a prominent goal for many national governments (Cooney 2012) because entrepreneurial activity increases employment (Kirchhoff and Phillips 1988) and influences the economy at the regional and national levels (Jinpei Wu 2009). Small firms have a potential to provide the ideal environment for enabling entrepreneurs to optimally exercise their talents, and to attain their personal and professional goals (Federal Democratic Republic of Ethiopia (FDRE) Ministry of Trade and Industry (MoTI) 1997). However, many small firms operate in a very competitive environment with increased risk and inability to forecast in the current unstable economy (Ndirangu and Mukulu 2014). Competitors with access to much larger pools of strategic resource have a greater flexibility in managing their external activities - timing of promotional campaigns, new product launches, and so

(c) The Author(s). 2018 Open Access This article is distributed under the terms of the Creative Commons Attribution 4.0 International License (http://creativecommons.org/licenses/by/4.0/), which permits unrestricted use, distribution, and reproduction in any medium, provided you give appropriate credit to the original author(s) and the source, provide a link to the Creative Commons license, and indicate if changes were made. 
on (Bianchi et al. 2012). In Ethiopia, small firms contribute less in job creation and development of economy when compared with counterparts in other countries due to financial problem, lack of qualified employees, lack of proper financial records, marketing problems, and lack of working premises and raw materials. Lack of information about market opportunities and standards and regulations is one of the underlying factors that hinder their performance (Gebreeyesus 2009).

According to Wiklund and Shepherd (2005), entrepreneurial orientation (EO) provides small businesses with the ability to discover new business opportunities and the discovery of new opportunities enhances their differentiation from other firms (Omisakin et al. 2016). The adoption of an entrepreneurial orientation as an indispensable variable to the growth oriented small firms seems pertinent (Ferreira and Azevedo 2008) because it is a significant contributor to a firm's success (Mahmood and Hanafi 2013). In fact, high EO among small business owners enhances the formation and activation of personal strategies affecting business growth and performance (Omisakin et al. 2016).

It is not surprising that firms benefit from adopting and practicing entrepreneurial orientation in an effective way. This is because firms need to look for opportunities continuously by searching new market and identifying new product, taking a calculated risk that brings an attractive result, competing aggressively to win competitors, and following participative management system to encourage workers' participation in innovation and a new way of doing things. All these activities need to undertake to improve their performance. The firms are uncertain about their existence without employing entrepreneurial orientations since firms are highly competitive, and technology and other environments are rapidly changing.

Even though firm performance is a focus area in the strategy of many owners/ managers of small firms, many researchers have targeted investigating the factors that affect firm performance, while the moderators used are different among different authors. Among the moderators, a firm's resources, firm size, firm age, and educational level are widely used. However, we did not find the test of moderating impact of firm's business sector and enterprises location in the relationship. The contribution of EO towards the performance of small ventures is different for the firms operating in different sectors and different locations. More specifically, ventures operating in cities perform better than ventures in small towns and rural areas and firms involved in industrial sectors perform better than firms involved in the service sectors.

To fill the gap, the following questions were answered; what is the current level of entrepreneurial orientation practice among small firms? What is the current level of performance among small firms? Do the Entrepreneurial orientation affect small business performance? Do a firm's business sector and operating location moderate the relationship between EO and firm performance? Therefore, the findings of this study enable small firm owner/manager to better understand how to enhance their business performance. This study has also implications for policy makers and other parties involved in the promotion of small firms to see the need to support small firms, which would reduce unemployment for the youth, fulfill infrastructure and create meaningful results on the economic development. In addition, this study makes several contributions to the fields of entrepreneurial orientation and venture performance through a comprehensive review of the literature and empirically testing the connections. 


\section{Theory and hypotheses}

\section{Entrepreneurial orientation}

Entrepreneurial orientation (EO) is a firm's ability to innovate, take risks, and proactively pursue market opportunities (Rauch et al. 2009; Wiklund and Shepherd 2005). Jinpei (2009) stated that Entrepreneurial orientation is defined as an individual's attitude towards engaging in entrepreneurial activities, be it within an existing firm or creating a new venture. On the other hand, the term "entrepreneurial orientation" has been used to refer to the strategy making processes and styles of firms engaged in entrepreneurial activities (Lumpkin and Dess 2001). It captures the entrepreneurial aspects of a firm's decision-making styles, methods, and practices of (Lumpkin and Dess 1996; Wiklund and Shepherd 2005). Rauch et al. (2009) conclude that EO represents the policies and practices that provide a basis for entrepreneurial decisions and actions. Therefore, EO influences entrepreneurs and small business owners in their engagement in business and product innovation, and market development (Carland et al. 1984). Generally, entrepreneurial orientation allows a firm to develop ideas and realize them in the form of new products and services, participate in risky projects, predict future requirements, and find new market opportunities (Covin and Slevin 1989).

\section{Entrepreneurial orientation and venture performance}

According to Venkatraman and Ramanujam (1986), performance can be measured with financial and operational (non-financial) indicators. Objective financial data for many businesses are not publicly available, and respondents are often unable or unwilling to provide the desired organization-level objective information (Fiorito and LaForge 1986,). Yet, subjective measures depend on judgmental assessments of respondents and these indicators cover both financial and non-financial indicators (Gonzalez-Benito and Gonzalez-Benito 2005). As a result, subjective performance measures may yield more complete information (Covin and Slevin 1989). Generally, many researchers recommend subjective measures of performance over objective measures.

Today's dynamic business environment requires a firm to regularly innovate, take risk into account, give room for autonomy, be proactive, and aggressively compete to maintain or find a new position in the market place (Omisakin et al. 2016). The characteristics and motivations of small firm owner-managers have considerable influences on the performance of their firms (Davidsson 1989). Wang (2008) posits that EO is important for business performance. This suggests that firms adopting more EO perform better than those that lack such orientation (Omisakin et al. 2016). Other research suggests that entrepreneurial firms may benefit more from imitation than from high levels of innovativeness (Lumpkin and Dess 1996). In summary, the results of many studies indicate the positive relationship between EO and performance.

\section{Innovativeness and firms performance}

Covin and Slevin (1989) define innovativeness as the firm's propensity to engage in new idea generation, experimentation, and research and development activities. Innovativeness is also defined as a firm's ability and attempt to engage in new ideas or to innovate and create processes that may result in new products (Rauch et al. 2009). Covin and Miles (1999) agree that without innovativeness, entrepreneurship cannot exist and that 
innovativeness is a crucial part of firm survival strategies (Omisakin et al. 2016). A number of research has found a positive relationship between innovation and firm performance (Rauch et al. 2009; Justine et al. 2005). As a result, the importance of innovation as a contributing variable to the measurement of EO and performance is incontrovertible (Omisakin et al. 2016). Therefore, the following hypothesis were developed.

H1a: Innovativeness dimension of EO positively influences ventures performance

\section{Proactiveness and firms performance}

Proactiveness relates to forward-looking, first mover advantage-seeking efforts to shape the environment by introducing new products or processes ahead of the competition (Rauch et al. 2009; Lyon et al. 2000). Proactive companies perform better than rivals because they respond market changes instantly (Hughes and Morgan 2007), they become leaders of the industry with opportunities they find before their rivals (Lumpkin and Dess 1996). Many studies on the relationship between EO and performance/growth have found positive relationship between proactiveness and performance (Lumpkin and Dess 2001; Hughes and Morgan 2007; Rauch et al. 2009; Sascha et al. 2012). Therefore, our hypothesis also proposes a positive influence of proactiveness on performance.

H1b: Proactiveness dimension of EO positively influences venture performance

\section{Risk taking and firms' performance}

Lumpkin and Dess (2001) argue that risk-taking refers to taking calculated business opportunities when the outcome of the risk cannot be determined immediately. Similarly, Wiklund and Shepherd (2003) suggest that risk-taking orientation is the willingness of an entrepreneurial firm to invest resources in a venture where the outcome may be highly uncertain or unknown (Omisakin et al. 2016). Risk taking consists of activities such as borrowing heavily, committing a high percentage of resources to projects with uncertain outcomes, and entering unknown markets (Lyon et al. 2000). Therefore, risk taking will contribute for the performance of ventures.

H1c: Risk taking dimension of EO positively influences ventures performance

\section{Competitive aggressiveness and firms performance}

Competitive aggressiveness refers to a firm's propensity to directly and intensely challenge its competitors to enter the market or improve its position, that is, to outperform rivals in the market place (Lumpkin and Dess 1996). Competitively aggressive firms often respond to such challenges with head-to-head confrontation (Shan et al. 2016). Mahmood and Hanafi (2013) examine the mediating effect of competitive advantage on the relationship between entrepreneurial orientation and performance of women-owned small and medium enterprises (SMEs) in Malaysia. Competitive aggressiveness has been found to enhance firm performance (Lyon et al. 2000). Justine et al. (2005) found a positive relationship between competitive aggressiveness and firm performance.

H1d: Competitive aggressiveness positively influences venture performance 


\section{Autonomous and firms performance}

Autonomy refers to the independent action of an individual or team in bringing forth an idea or vision and bringing it to fruition (Lumpkin and Dess 1996). It reflects the strong desire of a person to have freedom in the development and implementation of an idea within an organization (Lumpkin et al. 2009). Evidence of autonomy in firms may vary as a function of size, management style, or ownership (Lumpkin and Dess 1996), for example Justine et al. (2005) find that autonomy have a positive impact on the performance. The opinions and empirical evidence from research have concluded that autonomy enhances the firm's positive performance (Omisakin et al. 2016). Generally, all the components of entrepreneurial orientation are positively related with performance of small firms.

H1e: Autonomous dimension of EO positively influences venture performance

\section{Moderators}

Entrepreneurial orientation is widely acknowledged as a strong predictor of firm performance. There is little consensus on what constitutes suitable moderators, however, there are both external and internal variables (Wiklund and Shepherd 2003) and various environmental variables (Tan and Tan 2005) that moderate the relationship. Investigations on the direct effect of EO on firm performance have not provided a comprehensive description of the relationship (Wang 2008; Wiklund and Shepherd 2005), whereas some of the research in this area ignores factors that may moderate the strength of EO on firm performance (Omisakin et al. 2016). Wiklund and Shepherd (2003, 2005) indicate that EO has a positive influence on firm performance by taking into consideration certain environmental factors that may have a moderating effect on the EO-performance relationship.

The intervening variables in the study of Davidsson (1989) refer to the characteristics of the industry and the firm as well as those of the individual differences attributable to characteristics of the industry. In this study, we hypothesize that firm's established location and enterprise sector moderate the relationship because the firms operating in different sectors may practice EO differently. The relationship between entrepreneurial orientation and a business' performance varies depending on the industry (Zahra 2008). Industry type (Hitt and Tyler 1991) may affect the complexity and styles of strategy making (Dess et al. 1997). We also observed that firms located in different location practice EO differently and also grow differently. As such, we proposed that,

$\mathrm{H} 2$ : The involvement of firms in manufacturing sector intensifies the positive influence of entrepreneurial orientation on the ventures performance.

H3: The establishment of firms in larger cities intensifies the positive influence of entrepreneurial orientation on the ventures performance.

\section{Control variables}

Given that a firm's performance and the level of entrepreneurial orientation can vary within firms depending on their age and size (Lumpkin and Dess 1996; Van Doom et al. 2013; Wales et al. 2013; Shirokova et al. 2015). Businesses of different size and age 
may exhibit different organizational and environmental characteristics, which in turn may influence performance (Wiklund and Shepherd 2005). Therefore, these variables were included as controls.

The firm age is measured as the number of years (Shirokova et al. 2015). The older a firm is, the more hierarchy and inertia it has and thus the less it is motivated to shift organizational directions by innovating new products or services (Huergo and Jaumandreu 2004). Similarly, Luo et al. (2005) argue that younger firms are more likely to exhibit entrepreneurial strategic behaviors. Conversely, managers of younger firms lacking established business processes, experiential market knowledge, and well-developed organizational norms often engage in excessive trial and error behavior, resulting in diminished capacity to link strategic moves to performance outcomes (Slevin and Covin 1997). The EO-performance relationship would be strongest among younger firms (Anderson and Eshima 2013).

Several research found that firm size has a positive relationship with EO in SMEs (eg. Stam and Elfring 2008). Wiklund (1999) asserts that EO strengthens the performances of small firms because smallness fosters the flexibility needed to make EO initiatives successful. On the other hand, smaller firms may face more severe challenges in exploiting opportunities because of their small resource bases (Stam and Elfring 2008). Majority of studies have found that men have a greater probability of becoming entrepreneurs compared to female (Allen et al. 2008; Wagner 2007; Bernat et al. 2016). Lorunka et al. (2011) found that the founder's gender is important factors in predicting growth in a small enterprise. The impact of the independent variables on entrepreneurship is the same for both men and women (Bernat et al. 2016).

\section{Methods}

\section{Research design and sample size}

This study has a descriptive and explanatory research design. In selecting respondents to obtain primary data, we applied two levels of multi-stage sampling. In the first stage, central part of Ethiopia has been selected judgmentally since many of the small firms operating in the central part of the country. In the second stage, a sample of five cities with a large number of MSEs were selected. The researchers focused only on the grown small enterprises that are registered, licensed formally and currently operating under federal micro and small enterprise development agency (FeMESDA). These firms are categorized under three different sectors including manufacturing, construction, service, trade, and urban farming, in which all are considered for the sample.

A sample of 226 owners/managers were selected using convenience sampling technique from the Small firms in central Ethiopia, which involved in five different sectors. Out of these firms, the responses of 210 firms were validated and used for the analysis. For sample size selection, the sample size determination range developed by Malhorta Naresh was adopted. For instance, there are 1139 small firms grown to medium enterprise in the last 5 years in Addis Ababa (capital city), which fall in the fifth range in Malhorta Naresh's sample size determination table. In this range, a large sample size of 125 respondents was selected from Addis Ababa. The number of firms grown to medium enterprise in Debre Berhan, Fiche, and Ambo is 17, 18, and 16 respectively. Therefore, the highest sample of 125 from Addis Ababa, 50 from Adama, 16 from Ambo, 18 from Fiche and 17 from Debre Berhan were selected. 


\section{Data collection instruments}

The questionnaires that consisting of three parts which were developed partly by using a seven-point Likert scale were distributed to the selected owner/managers. Researchers use different instruments to measure performance that is classified under financial and non-financial performance. The operational performance captures indicators such as the introduction of new products, market-share, product quality, and the like (Weezel 2009). According to Wiklund and Shepherd (2005), performance is multidimensional in nature, and it is therefore advantageous to integrate different dimensions of performance in empirical studies. Gonzalez-Benito and Gonzalez-Benito (2005) suggest the use of subjective measures because subjective measure facilitates the measurement of complex dimensions of performance. Therefore, in this study, venture's performance was measured non-financially by the responses to three performance indices using a 7-point Likert scale ranging from 1 'Much Worse' to 7 'much better', for all four items: improvement in profitability, sales, resource, and employee.

The EO scale consists of nine items under three dimensions of innovativeness, pro-activeness and risk-taking (Covin and Slevin 1989). Okhomina (2010) used four dimensions of entrepreneurial orientation that were measured using a thirteen-item, 7-point Likert-type scale designed to measure respondents' entrepreneurial orientation. Later, Hughes and Morgan (2007) used the 14 item questionnaire for Entrepreneurial orientation that is measured on seven point Likert scale. Hughes and Morgan (2007) modified and developed to capture the entrepreneurial orientation dimensions of innovativeness, proactiveness, risk-taking, competitive aggressiveness and autonomy and gauged on a seven-point Likert scale. We adopted this measure for our study as a measure of EO by making minor modification on some items of competitive aggressiveness and autonomy. The items used for competitive aggressiveness includes, "In general, our business takes a bold or aggressive approach when competing" and "We try to undo and out-maneuver the competition as best as we can." The modified items used for autonomous includes "Employees are permitted to communicate and act without interference", "Employees independently perform jobs that allow them to make and instigate changes in the way they perform their work task.", and "Employees are given authority and responsibility to act alone if they think it to be in the best interests of the business." The higher score reflects higher levels of entrepreneurial orientation.

The sector in which firms operate includes manufacturing, construction, service, trade, and urban farming. The sector type is dummy coded as 0 for the manufacturing industry and 1 for another sector. The firms were categorized to city firms and regional town firms. Regarding the control variables, firm age was measured by the number of years since the firm's establishment (Shirokova et al. 2015). The dummy variable for firm age is coded as $0=$ firms established before 10 years, and firms with 10 or fewer years in the establishment are coded as 1 . Finally, to determine the size of firms, we used the number of permanent and temporary employment under an enterprise for this research, and we coded 0 for firms with less than 30 employees and 1 for firms with 30 or more workers.

The measurement instruments were tested for validity and reliability before analysis was made for completeness and compatibility with the purpose of the study. Pre-tests of the questionnaire was conducted with ten firms of varying sizes and belonging to different sectors for getting feedback about the clarity of the survey items and to test 
new questionnaire items developed for the research. Cronbach' alpha test of reliability was used to measure the reliability. The data gathered through questionnaires were analyzed and presented by quantitative methods of data analysis such as descriptive statistics analysis, correlation analysis, and multiple linear regression analysis. The results were interpreted using mean, standard deviation, and coefficients and presented quantitatively through tables and figures to give a condensed picture of the data.

\section{Results and analysis}

Results of descriptive statistics

The mean value 4.12 reveals that the average performance of firms is moderate. Regarding the control variables, the mean value for owner/manager gender is .20 that means females were about 2 out of 10 owners/managers. From this, we understand that most of the firms grown to medium enterprise are the firms led by males compared to females. The number of older firms that are grown to emerging medium enterprises is less than the younger firms. The firm size that is measured by a number of permanent and temporary workers is one of the items that is used to measure the growth of the firms and majority of our respondents have more than 30 workers, this is because the majority of our respondents are involved with the manufacturing and construction sectors which have numerous enterprises grown to emerging medium enterprises (Table 1).

Most of the dimensions of EO are moderately practiced in Ethiopia. We see that the firms in Ethiopia are moderately innovative, while they are moderately better in proactiveness. Regarding risk taking propensity, it is moderately low. Competitive aggressiveness and autonomous are also moderate. In addition, among the five sectors in which firms are involved, the manufacturing sector covers a large part of firms grown to an emerging medium enterprise. This reveals firms involved with this sector are more successful and grown to the medium level. The location in which firms established is also an important factor that contributes to the success of the firm. That is, there are more opportunities to grow in large cities than regional cities. Among the main effects, innovativeness, proactiveness, risk taking and autonomous are positively correlated with the

Table 1 Descriptive statistics results

\begin{tabular}{|c|c|c|c|c|}
\hline No. & Variables & Mean & Std. dev. & Pears. Corr. (2-tailed) \\
\hline 1. & Performance (Dependent) & 4.1238 & 1.3284 & 1.000 \\
\hline 2. & Firm size (control) & .3848 & .4813 & $.110^{* *}$ \\
\hline 3. & firm age(control) & .4048 & .4920 & -.287 \\
\hline 4. & Gender (control) & .2000 & .4010 & .016 \\
\hline 5. & Innovativeness(Independent) & 4.0429 & 1.4651 & $.713^{*}$ \\
\hline 6. & Proactiveness (Independent) & 4.6857 & 1.6848 & $249^{* * *}$ \\
\hline 7. & Risk taking(Independent) & 3.6000 & 1.7586 & $.617^{* *}$ \\
\hline 8. & Competitive aggressiveness(Independent) & 3.9571 & 1.7204 & .465 \\
\hline 9. & Autonomous (Independent) & 4.0095 & 1.6485 & $.804^{*}$ \\
\hline 10. & Business sector (Moderator) & .4429 & .4979 & .487 \\
\hline 11. & Enterprise location(Moderator) & .5905 & .4929 & -.545 \\
\hline
\end{tabular}


performance of ventures, while competitive aggressiveness is not significantly correlated with venture performance (Table 2).

\section{Results of regression analysis}

The adjusted $\mathrm{R}$ square .683 in the above table indicates that when entrepreneurial orientation dimensions are alone, approximately $68.3 \%$ of the variance of the performance of ventures is explained by them. But with the addition of moderator and interactions, the $\mathrm{R}$ square value increased to .711. That means when EO is combined with moderators and interactions, they explain of variance in the venture performance.

Firm size significantly influences the venture growth at the 0.1 significant level. Regarding the components of EO, proactiveness, risk-taking and autonomous variables significantly influence the venture growth in model 3 . The coefficient of a constant which is 1.739 at .000 indicates that control variables and main effect in common positively influence the venture's performance. The result of controls indicates, the more the number of employees, the better the growth of the enterprises and the younger the firms, the better the growth of ventures. A 1-standard deviation increase in proactiveness gives rise to a $7.0 \%$ increase in performance relative to the average performance level. This means as firms are more proactive, the performance of ventures improves. Similarly, a 1-standard deviation increases in risk taking gives rise to an $8.1 \%$ increase in performance relative to the average performance level. That is, risk taker firms tend to perform better than risk-averse firms. Finally, the influence of autonomy $(\beta=.157$, .000) on ventures performance is positively significant. That means as the ventures autonomous level increases the performance of the venture will increase. That is, a

Table 2 Regression analysis result for the relationship between EO and venture performance

\begin{tabular}{|c|c|c|c|c|}
\hline Variables & Model 1 & Model 2 & Model 3 & Model 4 \\
\hline $\mathrm{N}$ & 210 & 210 & 210 & 210 \\
\hline Age & $-.531(-3.230)$ & $-.263(-2.392)$ & $-.255(-2.434)$ & $-.214(-2.179)$ \\
\hline Size & $-1.232^{* * *}(-7.513)$ & $-.585^{* *}(-5.058)$ & $-.496^{* *}(-4.476)$ & $-.040^{*}(-4.762)$ \\
\hline Gender & $-.031(-.157)$ & $-.095^{* * *}(-.729)$ & $-.088^{* * *}(-.717)$ & $-.721^{* *}(-.201)$ \\
\hline Innovativeness & - & $.114(2.251)$ & $.081(1.674)$ & $.624(1.132)$ \\
\hline Proactiveness & - & $.178(4.181)$ & $.172^{* * *}(4.284)$ & $.243^{* *}(4.182)$ \\
\hline Risk taking & - & $.240(6.839)$ & $.190^{* * *}(5.477)$ & $.281^{*}(3.103)$ \\
\hline Compaggressiveness & - & $.037(.912)$ & $.025(.666)$ & $.225(.318)$ \\
\hline Autonomous & - & $.160(4.192)$ & $.157^{* * *}(4.330)$ & $.148^{* *}(4.611)$ \\
\hline Business sector & - & - & $-.278(-2.504)$ & $-.236(-2.475)$ \\
\hline Venture location & - & - & $.478(4.463)$ & $-.442(4.274)$ \\
\hline Innovativeness-business sector & - & - & - & $.249^{* *}(1.574)$ \\
\hline Proactiveness-business sector & - & - & - & $.107^{* * *}(3.782)$ \\
\hline Autonomous-business sector & - & - & - & $.014^{*}(4.765)$ \\
\hline Innovativeness-enterprise location & - & - & - & $.0273^{* *}(1.527)$ \\
\hline Constant & $4.844^{* * *}$ & $1.539^{* * *}$ & $1.739^{* * *}$ & $1.226^{* *}$ \\
\hline$R^{2}$ & .571 & .826 & .835 & .851 \\
\hline Adjusted $R^{2}$ & .326 & .683 & .698 & .711 \\
\hline
\end{tabular}

${ }^{* * *} p<0.01{ }^{* *} p<0.05{ }^{*} p<0.1$ 
1-standard deviation increase in autonomous gives rise to a $6.28 \%$ increase in performance relative to the average performance level.

Generally, the more a firm's proactiveness, risk taking, and autonomous, the better the performance of the firm. The moderating variables, business sector, and ventures location are added to the main effect and control variables. The constant increases from 1.539 to 1.739 in this model after moderators are added. This means the influence of the independent variables is improved with the moderators. Among the moderators, business sector has a significant influence on the performance. The overall influence of entrepreneurial orientation on performance enhances when the interaction of innovativeness and business sector, innovativeness and enterprise location, proactiveness and business sector, and autonomous and business sectors are added to the model (model 4). When all entrepreneurial orientation dimensions are combined with the business sector and enterprise location, the coefficient is 1.226 .

\section{Discussion}

\section{Ventures performance and transition}

Even though the firms selected for the study are the grown firms, they show a moderate performance. The performance of these ventures is better among young firms led by men, and ventures involved with the industrial sectors. The gender of owners/managers is dominated by males that mean women participated less as owner and manager of a firm. Regarding the firm size, the majority of firms have more than 30 workers and those are mostly the firms involved in manufacturing and construction sector. This is because the firms with less than 30 employees are service-oriented ventures including firms involved in a trade.

When we see the mean value of firm age, more than half of firms grown to start-up medium enterprises in the last 5 years are younger firms. This is because younger firms come up with new thinking, fresh ideas, and interest that make them give full consideration to their career. Among the sectors, the manufacturing sector is the highest grown sector comparatively.

The number of firms grown to start-up medium enterprise is higher in Addis Ababa than the summation of four regional towns selected for the study. This is why there are higher market and customers in larger cities than regional towns. Firms in capital cities have a higher potential for growth than firms established in regional towns because there are a large number of people in the city compared with the regional states, which contributes to higher customers and markets.

Regarding the sectors, the manufacturing sector is the highest in the number of existed firms. Specifically, in Addis Ababa, the manufacturing sector is approximately equal to the summation of all other sectors. That is, the manufacturing sector is more successful in larger cities. In the last 5 years, only a few of small firms have grown to a medium enterprise, in which most of them are involved with manufacturing and construction.

The total capital recorded and the level of employment is the higher among these two sectors. As a result, these two sectors have special consideration since they are contributing to the economy by reducing unemployment level and generating revenue 
for the members. The government also encourages firms which have grown to emerging medium enterprises to engage in these sectors.

\section{Entrepreneurial orientation practices Innovativeness}

The elements in innovation such as technology utilization, marketing, and management style are moderately utilized, but when we are comparing with other firms that are not transited and failed, the firms have grown to medium enterprise overweighs them. There is a high control on employees who are trying to apply their own work because the owner/managers believe that employees are not capable of improving the existing system. Most researchers in leadership recommend a close relationship between the manager and employees, but such kinds of relationship do not exist between owner/ manager and workers in most of the Ethiopian firms. This leads to the poor innovativeness of firms, which depends only on the leader even if small firms are a spring of new innovation. In most cases, these firms are unable to employ different marketing strategies such as promotion as it is applied by large firms.

\section{Proactiveness}

Most firms generated new actions which other competitors are following. They are the first in introducing new products/services, administrative techniques, and operating technologies comparatively, but in introducing new products/services or ideas they rely on a leader. This means being the first in providing goods/services with a new model, design, and different product is the key to attracting new customers and retaining the existing customers. However, the leaders were not providing sufficient incentives for individuals who are proactive in identifying and applying new ways before others. Comparatively, they are also finding a new market and customers before their competitors. The survival and growth of any firm depend on the market share and customer loyalty. Therefore, firms that identify and find a new market before the competitors are advantageous for getting a new customer that helps them to have larger market shares. Developing new administrative techniques and operating technologies prior to competitors are also helpful in getting things better done by workers and producing easily with low resource and effort. Saving resource and generating better outcome with minimum effort occurred because of new appropriate technology that varies the difference between revenue and cost. Generally, the secret for the growth of these enterprises is being the first in introducing a new product, technologies, and searching for new markets.

\section{Risk taking}

The owner/managers are reluctant to encourage the employees who are ready to take calculated risks and to try new products and ideas, while they emphasized on exploration and experimentation of employees. Most managers in small firms are not willing to distribute power and give freedom to their workers that hinder these employees to take a calculated risk that may help them to bring new ideas on the product, process, and technology. These make the firms not to try frequently the new products and ideas. On the other hand, firms attempt to explore opportunities that are found in their area, but it is not successful since only owner managers strive to search for opportunities. In 
most cases, the explored opportunities are not successful after experimentation. As risk aversion prohibits firms from exploiting new opportunities regarding production system, marketing, and technology. Extreme risk-taking can also hurt a firm due to facing undesirable risks, such as loss of money, equipment, key personnel, and customer leading a firm to failure.

\section{Competitive aggressiveness}

Even though they follow poor marketing strategy, they compete intensely and powerfully against their local small firm competitors rather than remaining status quo to avoid clashes. However, their competition against large firms is poor and they are not aggressive and compete harshly. Most of these firms are competing on product differentiation in manufacturing and service sector, while construction and trade sectors are competing on prices. The aggressive competitive measures that firms are taking to avoid failure help them to win and grow their enterprises. As we observed, most manufacturing industries, specifically metal and woodwork, and textile sectors are producing attractive design and a new model to attract customers and win the competition. Enterprises involved in the construction sector are mostly competing with a price to win a bid since most of their work is dependent on the bid. Even though they are primarily competing on a price, they also compete by developing new model and design.

\section{Autonomous}

The finding of the study shows that the firms are moderately autonomous because they strictly follow procedures and will not give complete freedom to workers in making decisions. The absence of independence and freedom prevents the enterprise from getting new ideas that contribute to the success of the firm. Therefore, the success of the firm depends on the skill of the manager, rather than being the outcome and effort of the enterprise's members. These cause the enterprises not to survive and transit to the next level. Theoretically, there is a closer control in small firms than large firms. Previously, our study subject is firms transited to start-up medium by winning the competition in small firms, but now they are supposed to compete against larger firms that give more freedom and independence, which contribute to the innovation of new processes, products, and technology.

\section{The role of entrepreneurial orientation on ventures performance}

The research on the relationship between EO and firms performance provides different findings. The direction of this relationship is also different between different studies. For example, some studies (Covin and Slevin 1986; Hult et al. 2003; Lee et al. 2001; Wiklund and Shepherd 2003, Kroeger 2007; Davis 2007; Giudici and Reinmoeller 2013; Zahra and Covin 1995; Ozgen and Baron 2007; Wiklund and Shepherd 2003; Lumpkin and Dess 1996; Covin and Slevin 1991; Wang 2008; Omisakin et al. 2016) find a positive relationship, while others (George et al. 2001; Covin et al. 1994) find no significant relationship between EO and performance. In our case, among the EO dimensions proactiveness, risk taking, and autonomous are significantly positively related to firms growth, while innovativeness and competitive aggressiveness are not significantly related to ventures performance. The moderators also positively moderate this relationship. 
The firms involved in the manufacturing sector are proactive, risk takers, compete aggressively and autonomous than firms involved in other sectors. The specific jobs in this sector mainly include wood and metal work, textile and garment, leather and leather products, and construction input production. As a result, it is easy to introduce new product and design, a new way of doing things, and new technology. These firms compete not only by price, but also compete on design, quality, and appearance of their products. Most ventures involved with the industrial sectors are generating new actions, including finding new market and customers before the others because they have to design differently and bring a new model before others.

The owners/managers of industry sector ventures emphasized more on the exploration and experimentation by employees. Therefore, EO influences venture performance in this sector more than their counterparts. The industry sector is larger in size than service and trade sectors in which high control of employees who are trying to apply for their own work because the owners/managers believe that employees are not capable of improving the existing system. The emphasis on the marketing of tried and true product/services is also better for these firms. That is, the less the control and the more emphasis on tried and true products in an industry sector, the better the performance of ventures.

The location also positively moderates the relation between EO and venture performance. Firms located in the larger city are more innovative, proactive, competitive and autonomous than firms established in regional towns. These are because of high competition in the large city, which encourage firms to innovate a new way of doing things and technology that helps to produce new products, and to search for new markets. A risk is associated with activities that have good promise to return. As a result, firms in larger cities are more autonomous and risk takers. In general, firms involved with the manufacturing sector and adopting strong EO tend to perform more than their relatives. Besides, firms located in larger cities that adopt EO grow much better than enterprises established in regional towns. More specifically, the performance of ventures in larger cities is better than the ventures in regional towns because of the better practice of EO in larger cities.

The introduction of new products/services, administrative techniques, and operating technologies are better among firms established in larger cities because they are the first in getting new technologies imported. In addition, the number of products/services users and competitors are higher in larger cities that make them provide goods/services differently with a new model, design, and different product to win the competition. Most managers of small ventures in regional towns are not willing to distribute power and give freedom to their workers that hinder these employees to take a calculated risk than venture managers in larger cities. These make the ventures to try frequently the new products and ideas generated from all workers. This is why the growth of ventures in larger cities is better than the ventures in regional towns. The level of innovation in products, technologies, and markets is higher among firms operating in the capital city than firms in regional towns because there are larger ventures in city areas from which small firms learn. The absence of independence and freedom prevents the enterprise from getting new ideas that contribute to the success of the firm in regional towns. Regarding the control variables, we find that younger firms perform well to grow towards the next level better than the older one and firms with a large number of workers tend to grow more. 
Even though innovativeness does not affect the performance alone, the interaction of innovation with the business sector and enterprise location influences the performance positively. That is, the firms who are innovative and involved with the manufacturing sector will perform more than their counterparts. Similarly, innovative firms located in larger cities perform better than their counterparts.

\section{Conclusions and implications}

\section{Conclusion}

The performance and entrepreneurial orientation practice among Ethiopian small enterprises are moderate. In general, entrepreneurial orientation positively influences ventures performance, and specifically, proactiveness, risk-taking, and autonomous dimensions positively determine venture performance. The level of influence is increasing as firms are involved with the manufacturing sector since the entrepreneurial orientation is better and contributed more to the venture's performance in this sector. Similarly, the level of influence is increasing as firms are being established in larger cities because the firms in cities have more customers and competitors causing them to generate unique strategies that lead them to outstanding performance. Moreover, younger ventures with new ideas and effort and ventures with a large number of workers have a better performance than older and ventures with a small number of workers.

\section{Practical implications}

It is widely recommended for small and medium enterprises to employ entrepreneurial orientation for their venture performance. In addition, there are also other variables that facilitate the effective utilization of entrepreneurial orientation for a better venture performance. The extent of influence is also different for different firms operating in different situations. Therefore, by taking into account the findings of our study, we recommend the following suggestions for government bodies and venture owner/managers. The entrepreneurial orientation activities are moderately practiced during their growth to medium-sized enterprises, but this is not adequate for competing with the existing medium and larger enterprises. Therefore, the enterprise's owner/manager should improve developing new products, entering new markets, introducing new technology, taking new ideas from working members, competing aggressively, and working autonomously by taking calculated risks. The impact of entrepreneurial orientation on the performance of ventures is higher when firms are involved with the industrial sector and operating in a city with a large number of populations. As a result, the owner/managers should assess and recognize the sector in which they involve and the location in which they are operating.

\section{Limitations and future implications}

This study is not without limitation. First, the study was conducted on only firms transited from small scale to medium-sized enterprises which didn't include failed firms. However, it would have a paramount importance if firms not transited to the next stage were also included. Secondly, the study area from which primary data obtained is limited to central Ethiopia, while it could be more representative if more study areas were included in the study. Third, data was collected in one shot. Thus, considering these 
limitations, we suggest the following ideas for further research. First, it has more importance if the strategies of both transited and failed enterprises are studied comparatively to differentiate the working and poor strategies. Second, we suggest future research to include more study areas under consideration. Finally, we recommend researchers to undertake a longitudinal study to identify the progress of these firms in order to test their impacts on performance adding more variables including the bank finance, venture capital, and angel investors.

Abbreviations

EO: Entrepreneurial orientation; FeMESDA: Federal micro and small enterprise development agency; SMEs: Small and medium enterprises

\section{Acknowledgements}

The authors wish to thank the editor-in-chief and the external language editor for their helpful contribution. Many thanks to the anonymous reviewers for insightful comments and suggestions. We also thank the respondents for responding to the questionnaire, we distributed to them.

\section{Authors' contributions}

All the three authors collected the data, performed the statistical analysis, and drafted and approved the final manuscript.

\section{Competing interests}

The authors declare that they have no competing interests.

\section{Publisher's Note}

Springer Nature remains neutral with regard to jurisdictional claims in published maps and institutional affiliations.

\section{Author details}

${ }^{1}$ Department of Entrepreneurship and Business Management, Kotebe Metropolitan University, Addis Ababa, Ethiopia. ${ }^{2}$ Department of Management, Debre Berhan University, Debre Birhan, Ethiopia. ${ }^{3}$ College of Business and Economics, Debre Berhan University, Debre Birhan, Ethiopia.

Received: 7 August 2017 Accepted: 20 August 2018

Published online: 04 September 2018

\section{References}

Allen, E., Elam, A., Langowitz, N., \& Dean, M. (2008). Global entrepreneurship monitor 2007: Report on women and entrepreneurship. Babson Park, MA and London: Babson College and London Business School. http://zsbapp.baruch.cuny.edu/download/ centers/field/global-entrepreneurshipmonitor/Women's_Full_GEM_Report_081a.pdf.

Anderson, B. S., \& Eshima, Y. (2013). The influence of firm age and intangible resources on the relationship between entrepreneurial orientation and firm growth. J Bus Vent, 28, 413-429.

Bernat, L. F., Lambardi, G., \& Palacios, P. (2016). Determinants of the entrepreneurial gender gap in Latin America. Small Bus Econ. https://doi.org/10.1007/s11187-016-9789-7.

Bianchi, C., Winch G.W., Cosenz, F. (2012). Sustainable strategies for small Competing Against Multinational Giants. Paper Presented At ACERE Diana Conference, Freemantle -Perth. www.researchgate.net/profile/Carmine_Bianchi3/publication/ 233832698.

Carland, J. W., Hoy, F., Boulton, W. R., \& Carland, J. A. C. (1984). Differentiating entrepreneurs from small business owners: A conceptualization. Acad Manage Rev, 9(2), 354-359.

Cooney, T. M. (2012). Entrepreneurship Skills for Growth-Orientated Businesses. Report for the Workshop on 'Skills Development for SMEs and Entrepreneurship, Copenhagen. http://www.oecd.org/cfe/leed/cooney_entrepreneurship_ skills_HGF.pdf.

Covin, J., \& Miles, M. (1999). Corporate entrepreneurship and the pursuit of competitive advantage. Entrepreneurship: Theory \& Practice, 23(3), 47-63.

Covin, J. G., \& Slevin, D. P. (1986). The development and testing of an organizational-level entrepreneurship scale. In R. Ronstadt, J. A. Hornaday, R. Peterson, \& K. H. Vesper (Eds.), Frontiers of entrepreneurship research (pp. 628-639). Wellesley, MA: Babson College.

Covin, J. G., \& Slevin, D. P. (1989). Strategic management of small firms in hostile and benign environments. Strategic Management Journal, 10(1), 75-e87.

Covin, J. G., \& Slevin, D. P. (1991). A conceptual model of entrepreneurship as firm behavior. In Entrepreneurship Theory and Practice, 16(1), 7-25.

Covin, J. G., Slevin, D. P., \& Schultz, R. L. (1994). Implementing strategic missions: Effective strategic, structural and tactical choices. Journal of Management Studies, 31(4), 481-505.

Davidsson, P. (1989). Entrepreneurship - and after? A study of growth willingness in small firms. Journal of Business Venturing, 4, 211-226.

Davis, J. L. (2007). Firm-level entrepreneurship and performance: An examination and extension of relationships and measurements of the entrepreneurial orientation construct. Unpublished Thesis, University of Texas. https://rc.library.uta. edu/uta-ir/bitstream/handle/10106/554/umi-uta-1712.pdf?. 
Dess, G. G., Lumpkin, G. T., \& Covin, J. G. (1997). Entrepreneurial strategy making and firm performance: Tests of contingency and configurational models. Strategic, Management Journal, 18(9), 677e695.

Federal Democratic Republic of Ethiopia (FDRE) Ministry of Trade and Industry (MoTI). (1997). Micro and Small Enterprise Development Strategy. Addis Ababa, Ethiopia.

Ferreira, J., \& Azevedo, S. G. (2008). Entrepreneurial orientation and growth of firms: Key lessons for managers and business professionals, Problems and Perspectives in Management.6(1), 82-88.

Fiorito, S. S., \& LaForge, R. W. (1986). A marketing Strategy Analysis of Small Retailers. Entrepreneurship Theory and Practice, 10(4), 7-18.

Gebreeyesus, M. (2009). Innovation and Micro enterprises Growth in Ethiopia. World Institute for Development Economics Research, Research Paper No. 2009/51. https:/pdfs.semanticscholar.org/b00f/946cc71fd99daac4200fd91fa4cbcf32c1db.pdf.

George, G., Wood, R. D., \& Khan, R. (2001). Networking strategy of boards: Implications for small and medium-sized enterprises. Entrepreneurship and Regional Development, 13(3), 269-285.

Giudici, A., \& Reinmoeller, P. (2013). Sensing together: an exploration of the support of network intermediaries to firms' and entrepreneurs' search for new opportunities. Unpublished Thesis, Granfield University. https://dspace.lib.cranfield.ac.uk/ handle/1826/7956.

Gonzalez-Benito, O., \& Gonzalez-Benito, J. (2005). Cultural vs. operational market orientation and objective vs. subjective performance: Perspective of production and operations. Industrial Marketing Management, 34, 797-829.

Hitt, M. A., \& Tyler, B. B. (1991). Strategic decision models: Integrating different perspectives. Strategic Management Journal, 12(5), 327-351.

Huergo, E., \& Jaumandreu, J. (2004). Firms' age, process innovation and productivity growth. International Journal of Industrial Organization, 22(4), 541-559.

Hughes, M., \& Morgan, R. E. (2007). Deconstructing the relationship between entrepreneurial orientation and business performance at the embryonic stage of firm growth. Industrial Marketing Management, 36(5), 651-661.

Hult, G. T. M., Ketchen Jr., D. J., \& Nichols Jr., E. L. (2003). Organizational learning as a strategic resource in supply management. Journal of Operations Management, 21, 541-556.

Jinpei Wu. (2009). Entrepreneurial orientation, entrepreneurial intent and new venture creation: Test of a framework in a Chinese context, PHD dissertation, Blacksburg, Virginia. http://hdl.handle.net/10919/28298.

Justine, A., Anthony, L., \& Max, C. (2005). The impact of entrepreneurial orientation on the Australian automotive component industry. Working paper 17/05, Department of management, Monash University. http://pandora.nla.gov.au/pan/44459/ 20070123-0000/wp17-05.pdf.

Kirchhoff, B. A., \& Phillips, B. D. (1988). The effect of firm formation and growth on job creation in the United States. Journal of Business Venturing, 3(4), 261-272.

Kroeger J W. (2007). Firm Performance as a Function of Entrepreneurial Orientation and Strategic Planning Practices. ETD Archive. Paper 170. https://engagedscholarship.csuohio.edu/etdarchive/170/.

Lee, C., Lee, K. \& Pennings, J.M. (2001). Internal capabilities, external linkages, and performance. A study on technology-based ventures. Strategic Management Journal 22 nr.6-7 p.615-640

Lorunka, C., Kessler, A., Frank, H., \& Lueger, M. (2011). Conditions for growth in one-person startups: A longitudinal study spanning eight years. Psicothema, 23(3), 446-452.

Lumpkin, G. T., Cogliser, C. C., \& Schneider, D. R. (2009). Understanding and measuring autonomy: An entrepreneurial orientation perspective. Entrepreneurship Theory and Practice, 33(1), 47-69.

Lumpkin, G. T., \& Dess, G. G. (1996). Clarifying the entrepreneurial orientation construct and linking it to performance. The Academy of Management Review, 21(1), 135-172.

Lumpkin, G. T., \& Dess, G. G. (2001). Linking two dimensions of entrepreneurial orientation to firm performance: The moderating role of environment and industry life cycle. Journal of Business Venturing, 16, 429-451.

Luo, X., Zhuo, L., \& Liu, S. (2005). Entrepreneurial firms in the context of China's transition economy: An integrative framework and empirical examination. Journal of Business Research, 58, 277-284.

Lyon, D. W., Lumpkin, G. T., \& Dess, G. G. (2000). Enhancing entrepreneurial orientation research: Operationalizing and measuring a key strategic decision making process. Journal of Management, 26(5), 1055-1085.

Mahmood, R., \& Hanafi, N. (2013). Entrepreneurial orientation and business performance of women-owned small and medium Enterprises in Malaysia: Competitive advantage as a mediator. International Journal of Business and Social Science, 4(1).

Ndirangu, A. N., Mukulu, E. (2014). Effects of entrepreneurial training content on the growth of micro and small Enterprises in Kenya, Kangemi: Nairobi. The international journal of Business \& Management, 2(8), 85-91.

Okhomina, D. (2010). Entrepreneurial postures and psychological traits: The sociological influences of education and environment. To appear in Research in Higher Education Journal, 8, 20.

Omisakin, O. M., Nakhid, C., Littrell, R., Verbitsky, J., Omisakin, et al. (2016). Entrepreneurial orientation among migrants and small and medium enterprises. Journal of Business Administration Research, 5(1).

Ozgen, E., \& Baron, R. A. (2007). Social sources of information in opportunity recognition: Effects of mentors, industry networks, and professional forums. Journal of Business Venturing, 22(2), 174-192.

Rauch, A., Wiklund, J., Lumpkin, G. T., \& Frese, M. (2009). Entrepreneurial orientation and business performance: An assessment of past research and suggestions for the future. Entrepreneurship Theory and Practice, 33(3), 761e787.

Sascha, K. J. P., Coen, R., Marthew, H., \& Vincent, H. (2012). Entrepreneurial orientation and business performance of SMEs: A quantitative study from the Netherlands. Review of management science, 6(2), 161-182.

Shan, P., et al. (2016). Entrepreneurial orientation and performance: Is innovation speed a missing link? Journal of Business Research, 69(2016), 683-690.

Shirokova, G., Bogatyreva, K., \& Beliaeva, T. (2015). Entrepreneurial orientation of Russian firms: The role of external environment. Foresight and STI Governance, 9(3).

Slevin, D. P., \& Covin, J. G. (1997). Strategy formation patterns, performance, and the significance of context. Journal of Management, 23, 189-209.

Stam, W., \& Elfring, T. (2008). Entrepreneurial orientation and new venture performance: The moderating role of intra- and extra-industry social capital. The Academy of Management Journal, 51(1), 97-111. 
Tan, J., \& Tan, D. (2005). Environment- strategy co-evolution and co-alignment: A staged model of Chinese SOE's under transition. Strategic Management Journal, 26, 141-157.

Van Doom, S., Jansen, J. J., van den Bosch, F. A., \& Volberda, H. W. (2013). Entrepreneurial orientation and firm performance: Drawing attention to the senior team. Journal of Product Innovation Management, 30(5), 821-836.

Venkatraman, N., \& Ramanujam, V. (1986). Measurement of business performance in strategy research: A comparison of approaches. Academy of Management Review, 1(4), 801-808.

Wagner, J. (2007). Nascent Entrepreneurs. In P. Simon (Ed.), The life cycle of entrepreneurial ventures (pp. 15-37). Springer. https://www.springer.com/gp/book/9780387321561.

Wales, W. J., Gupta, V. K., \& Mousa, F. T. (2013). Empirical research on entrepreneurial orientation: An assessment and suggestions for future research. International Small Business Journal, 31(4), 357-383.

Wang, C. L. (2008). Entrepreneurial orientation, learning orientation, and firm performance. Entrepreneurship Theory and Practice, 32(4), 635-657.

Weezel, A.V. (2009). Entrepreneurial strategy-making mode and performance: A study of the newspaper Industry, JIBS Dissertation Series No. 055, Jönköping International Business School. http://hj.divaportal.org/smash/get/diva2:208695/ FULLTEXT01.pdf.

Wiklund, J. (1999). The sustainability of the entrepreneurial orientation-performance relationship. Entrepreneurship Theory and Practice, 24(1), 37-48.

Wiklund, J., \& Shepherd, D. (2003). Knowledge-based resources, entrepreneurial orientation, and the performance of small and medium sized business. Strategic Management Journal, 24(13), 1307-1314.

Wiklund, J., \& Shepherd, D. (2005). Entrepreneurial orientation and small business performance: A configurational approach. Journal of Business Venturing, 20, 71-91.

Zahra, S., \& Covin, J. G. (1995). Contextual influences on the corporate entrepreneurship—Performance relationship: A longitudinal analysis. Journal of Business Venturing, 10, 43-58.

Zahra, S. A. (2008). Being entrepreneurial and market driven: Implications for company performance. Journal of Strategy and Management, 1(2), 125-142.

\section{Submit your manuscript to a SpringerOpen ${ }^{\circ}$ journal and benefit from:}

- Convenient online submission

Rigorous peer review

- Open access: articles freely available online

- High visibility within the field

- Retaining the copyright to your article

Submit your next manuscript at $\boldsymbol{\nabla}$ springeropen.com 